\title{
ДОСЛЦДЖЕННЯ ТЕМПЕРАТУРНИХ ПОЛІВ ПРОЦЕСУ ГРАФІТУВАННЯ ВУГЛЕЦЕВИХ ВИРОБІВ
}

\author{
Жученко О.А., Волощук М.Г.
}

Національний технічний університет України «Київський політехнічний інститут імені Ігоря Сікорського», м. Київ, Україна

ORCID: 0000-0001-5611-6529 ${ }^{1}, 0000-0002-5317-3314^{2}$

E-mail: azhuch@ukr.net ${ }^{1}$, masha-voloshchuk@i.ua ${ }^{2}$

Copyright (C) 2018 by author and the journal “Automation technologies and business - processes. This work is licensed under the Creative Commons Attribution International License (CC BY). http://creativecommons.org/licanses/by/4.0
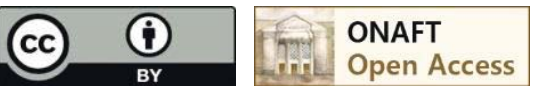

\section{DOI: 10.15673/atbp.v10i1.874}

Аннотація: Виробництво графітованої продукиії складне, багатостадійне та дуже енергоємне. На процес графітування впливає цілий ряд факторів, та головним чинником, який визначає якість готової продукції $\epsilon$ температурний режим обробки. Ця обставина зумовлює необхідність дослідження температурних полів, які формуються під час графітування вуглецевих виробів. У існуючих дослідженнях, які хоч і мають практичну иінність, та їх напрям і результати не спрямовані на побудову системи керування процесом. Підвищення ефективності останнього пов'язане зі створенням ефективної системи керування. Звичайно, для иього необхідне експериментальне дослідження на промисловому обладнанні та воно неможливе, оскільки може принести великі фінансові затрати у зв'язку з реальною загрозою випуску бракованої продукиії, та можливістю створення аварійної ситуації. У изих умовах єдиною альтернативою промисловим експериментам є дослідження за допомогою методу математичного моделювання. Процес графітування умовно можна поділити на два етапи - нагрівання та охолодження. Проводилось дослідження для чотирьох типів завантажень: заготовки діаметром 400, 500, 600 мм, а також комбіноване завантаження. Результати досліджень показали, щз нагрівання заготовок при різних типах завантаження печі відбувається із суттєво різною інтенсивністю. Характерною особливістю прочесу нагрівання є те, щзо найбільший перепад температур в усіх заготовках спостерігається фактично в один $і$ той самий час, але ичей час різний для варіацій діаметрів. Як і очікувалось, швидкість охолодження заготовок залежить від їх розмірів: чим більший діаметр, тим довше вони остигають, причому різниця у тривалості охолодження досить суттєва. Тобто, результати досліджень показали, щзо температурні поля процесу графітування вуглецевих виробів як у режимі нагрівання, так і у режимі охолодження суттєво залежать від типу заготовок, щзо завантажуються у піч, а також від їх розташування. Враховуючи суттєву температурну розподіленість процесу графітування, визначені місия розташування заготовок з найбільшою та найменшою температурами у досліджуваних режимах, які не змінюються у залежності від типу завантаження. На підставі проведеного дослідження повинна бути розроблена система керування проиесом графітування вуглецевих виробів.

Abstract: The production of grafite products is complex, multi-stage and very energy-intensive. A number of factors influence the process of grafitization, and the main factor determining the quality of finished products is the temperature processing mode. This circumstance necessitates the study of temperature fields formed during the grafitization of carbon products. In existing studies, which although of practical value, their direction and results are not aimed at building a process management system. Improving the efficiency of the latter is due to the creation of an effective management system. Of course, an experimental research on industrial equipment is needed for this, and it is impossible, as it can bring great financial costs due to the real threat of the production of defective products, and the possibility of creating an emergency situation. In these conditions, the only alternative to industrial experiments is the study using the method of mathematical modeling. The process of grafitization can be divided into two stages - heating and cooling. A study was conducted for four types of downloads: product preparation diameter of 400,500, $600 \mathrm{~mm}$, as well as combined loading. The results of the research have shown that the heating of the billets at different types of kiln loading occurs with a significantly different intensity. A characteristic feature of the heating process is that the greatest temperature difference in all the workpieces is observed at the same time, but this time is different for variations in diameters. As expected, the cooling rate of the billets depends on their size: the larger the diameter, the longer they cool, and the difference in the duration of cooling is quite significant. That is, the results of studies have shown that the temperature fields of the grafite process of carbon products, both in heating mode and in cooling mode, are significantly dependent on the type of blanks loaded in the furnace, as well as on their location. Given the significant 
temperature distribution of the grafite process, the locations of the billets with the highest and lowest temperatures in the investigated modes are determined, which do not change depending on the type of loading. On the basis of the conducted research, a system for controlling the process of grafitization of carbon products should be developed.

Ключові слова: графітування, піч Ачесона, температурні режими, температура, нагрівання, охолодження, ступінь графітування, система керування, моделювання.

Keywords: grafitization, Acheson's furnace, temperature mode, temperature, heating, cooling, degree of grafitization, control system, modeling.

Вступ

Вуглеграфітові електродні вироби, завдяки своїм унікальним фізико-хімічним властивостям, знайшли широке застосування у чорній та кольоровій металургії, машинобудуванні, хімічній промисловості, а також в інших виробництвах, пов’язаних з електротермією та агресивними середовищами технологічних процесів. Сучасні тенденції зростання потреби у графітованих виробах вимагають постійного нарощування обсягів виробництва.

Виробництво графітованої продукції складне, багатостадійне та дуже енергоємне. При цьому на заключну стадію графітування - припадає до 80 \% загальних енерговитрат [1], а питома кількість електроенергії, підведеної до печі Ачесона за період кампанії графітування, становить близько 6500 кВт·год/т. В умовах постійного зростання вартості електроенергії зменшення енерговитрат на графітування при забезпеченні високої якості кінцевої продукції має велике народно-господарське значення і тому $€$ важливою науково-технічною задачею. Розв'язання даної задачі пов'язане зі створенням сучасної системи керування, робота якої буде основана на аналізі поточного стану технологічного процесу.

Графітування великогабаритної продукції, до якої належать електроди дугових сталеплавильних печей, подові блоки алюмінієвих електролізерів тощо, як правило, здійснюють в електричних печах опору за технологією Ачесона [2]. Печі Ачесона характеризуються істотною нерівномірністю розподілу температурного поля та нестабільністю електро- та теплофізичних властивостей матеріалів завантаження. Особлива увага при виробництві електродних виробів з підвищеними експлуатаційними характеристиками приділяється забезпеченню однорідності їх фізичних властивостей.

На процес графітування впливає цілий ряд факторів, зокрема, індивідуальні властивості вуглецевих матеріалів, газове середовище, передісторія термічної обробки, тривалість процесу тощо. Вплив декотрих із них на процес графітування наразі до кінця не досліджений. Однак, як показують численні дослідження [2 - 6], головним чинником, який визначає якість графітування вуглецевої речовини є температурний режим обробки. Причому для отримання якісного штучного графіту кінцева температура повинна бути не нижче $2000-3000^{\circ} \mathrm{C}$.

Названі вище обставини викликають необхідність дослідження особливостей температурних полів, які формуються під час графітування вуглецевих виробів, з метою використання отриманих результатів для синтезу ефективної системи керування даним процесом.

\section{Аналіз існуючих досліджень}

У монографії [7] розроблена фізична та математична моделі процесу графітування у печах Ачесона 3 урахуванням теплоти хімічних реакцій газифікації кернової пересипки, піролізу деревини, відновлення оксидів металів, тепло- та масо-переносу водяною парою і контактної взаємодії механічної та теплоелектричної природи на границі сипучий матеріал - тверде тіло. Представлені результати експериментальних досліджень у печах графітування постійного та змінного струму. Теоретично досліджено вплив визначальних параметрів технологічного регламенту процесу графітування на механічний і теплоелектричний стан печей Ачесона.

У дисертації [1] велику увагу приділено експериментальному дослідженню температурних режимів процесу графітування у печі Ачесона. На жаль, результати даного дослідження мають обмежений характер у зв’язку 3 відсутністю технічних засобів для вимірювання надвисоких температур.

У праці [8] досліджувався вплив максимальної сили струму на динаміку температур у заготовках, розташованих у різних місцях печі Ачесона. Досліджувалась тільки одна кампанія графітування, тому іiі результати не можуть бути поширені на інші кампанії з іншими заготовками.

Результати іноземних дослідників не публікуються у відкритих джерелах.

Усі згадані вище дослідження, хоч і мають практичну цінність, але їх напрям і результати не спрямовані на побудову системи керування процесом графітування вуглецевих виробів.

\section{Постановка задачі}

Підвищення ефективності процесу графітування вуглецевих виробів пов'язане зі створенням і впровадженням ефективної системи керування. Синтез системи керування неможливий без попереднього дослідження технологічного процесу. Таке дослідження процесу графітування має на меті отримання відповідей на наступні питання:

1. Як відбувається нагрівання заготовок різного типу? Якщо заготовки нагріваються однаково, це означає, що можна сформувати єдину програму підведення енергії для всіх видів продукції, тобто реалізувати програмну систему керування.

2. Де розташовуються заготовки, які нагріваються найповільніше та охолоджуються найшвидше? Саме на ці заготовки повинна орієнтуватися система керування у зв'язку з тим, що саме заготовки з мінімальною температурою, а 
значить, з мінімальним ступенем графітування визначають загальну тривалість даного технологічного процесу для отримання готової продукції із заданим ступенем графітування.

3. Чи змінюється розташування заготовок з мінімальною та максимальною температурою у ході технологічного процесу?

4. Де містяться заготовки з максимальним перепадом температур під час нагрівання? Перепад температур, який перевищує допустиму величину, може призвести до механічних ушкоджень заготовок, а значить, до випуску бракованої продукції.

Для відповіді на поставлені питання потрібно провести трудомісткий процес експериментального дослідження на промисловому обладнанні. На жаль, це неможливо $з$ двох основних причин.

По-перше, таке дослідження потребує великих фінансових затрат у зв'язку з реальною загрозою випуску бракованої продукції. Крім того, не виключається ймовірність створення аварійної ситуації.

По-друге, у процесу дослідження треба вимірювати температури вищі за $2500^{\circ} \mathrm{C}$, на що немає технічної можливості. При цьому зовсім неможливим, з технічної точки зору, постає питання про вимірювання температури всередині заготовок, що обробляються.

У цих умовах єдиною альтернативою промисловим експериментам є дослідження за допомогою методу математичного моделювання.

Процес графітування вуглецевих виробів умовно можна поділити на два етапи - нагрівання та охолодження.

Метою даної статті є дослідження температурних полів процесу графітування вуглецевих виробів у режимах нагрівання та охолодження на основі методу математичного моделювання.

\section{Результати дослідження}

Для проведення даного дослідження була використана математична модель [1]. Дослідження кампанії графітування проводилось для чотирьох типів завантажень: заготовки діаметром 400, 500, 600 мм, а також комбіноване завантаження. Останнє передбачає завантаження заготовками таким чином: у верхньому ряді - діаметром 600 мм, у середньому - 500 мм та у нижньому - 400 мм. Геометрія печі та все електро- та теплофізичні константи були реалізовані згідно [1].

Режим нагрівання

Для з'ясування питання про можливість реалізації однакової програми підведення електроживлення печі графітування було проведене моделювання процесу нагрівання для всіх типів завантаження. Результати моделювання після 22 годин нагрівання представлені на рис. 1-4. 3 наведених результатів видно, що заготовки діаметром 400 мм за цей час досягають температури до $3000{ }^{\circ} \mathrm{C}$, що свідчить про інтенсивний процес графітування, який починається при температурі вище за $2000{ }^{\circ} \mathrm{C}$. При комбінованому завантаженні температури заготовок нижчі, ніж у попередньому випадку, але процес графітування проходить досить інтенсивно.

Для інших типів завантаження температура заготовок знаходиться у межах $2000-2300{ }^{\circ} \mathrm{C}$, що свідчить про те, що графітування або тільки починається, або ще не увійшло в інтенсивну фазу.

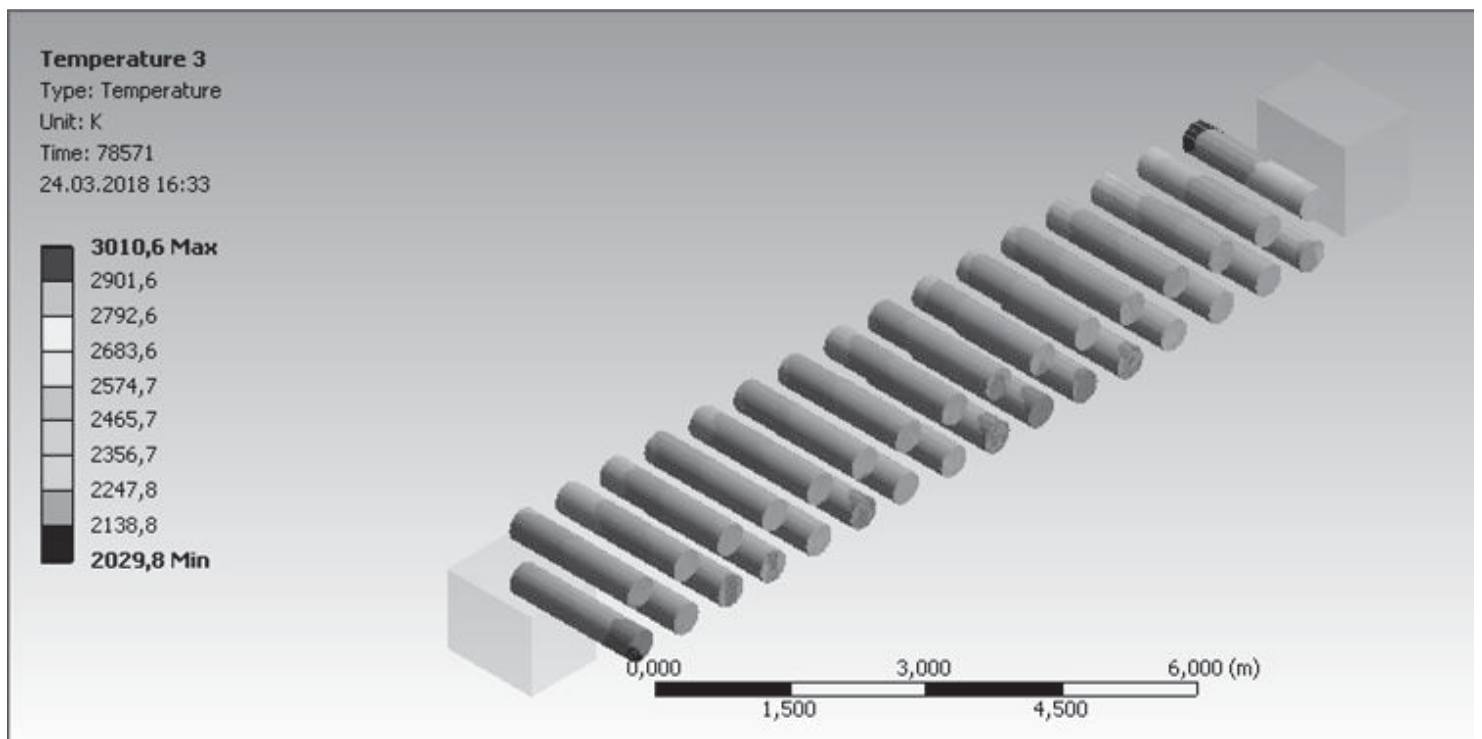

Рис. 1 - Температурні поля на розрізі печі по заготовкам кампанії графітування (діаметр виробів 400 мм) 


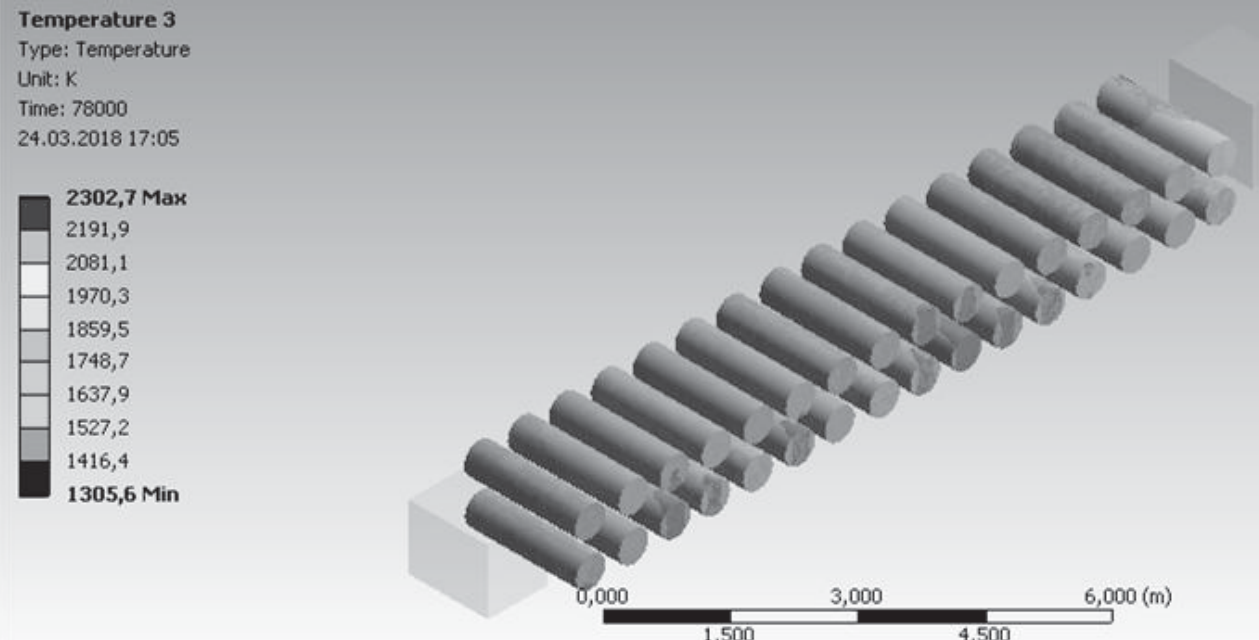

Рис. 2 - Температурні поля на розрізі печі по заготовкам (діаметр виробів 500 мм)
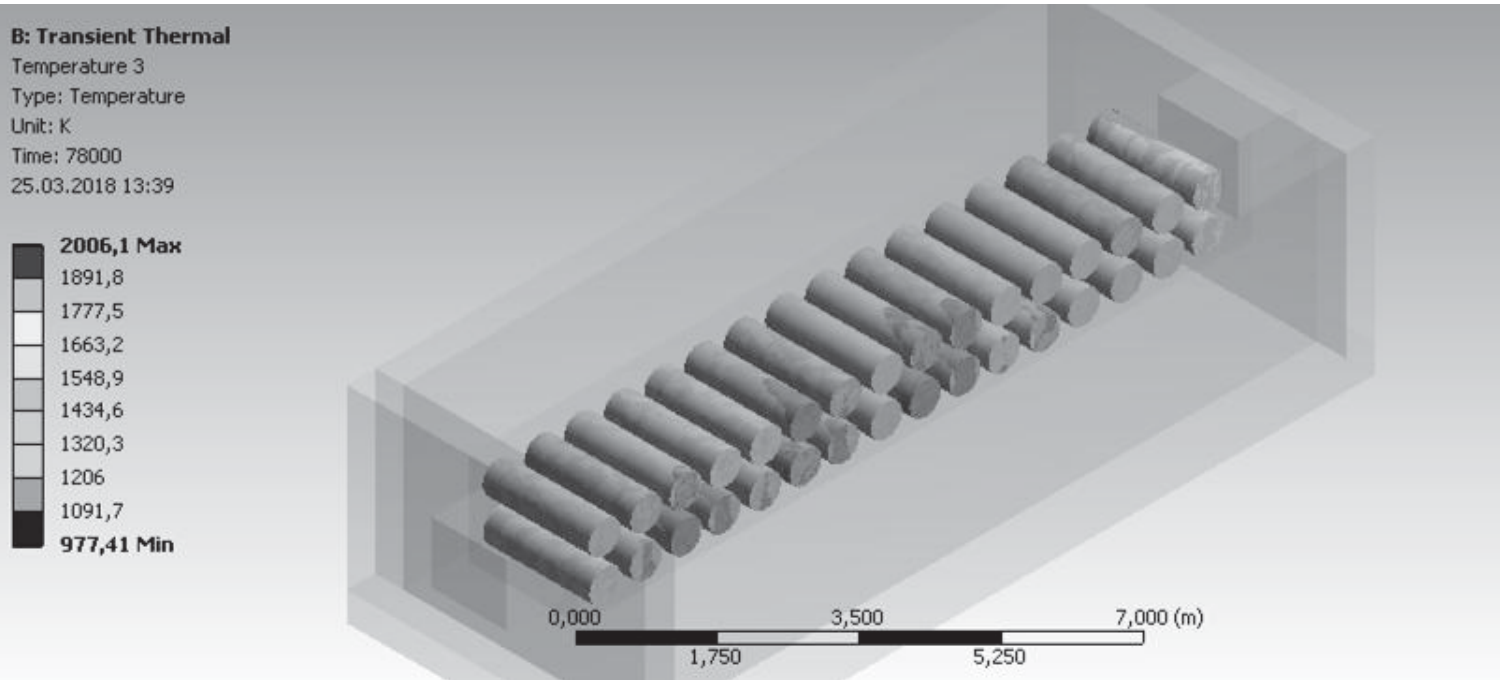

Рис. 3 - Температурні поля на розрізі печі по заготовкам (діаметр виробів 600 мм)

B: Transient Thermal

Temperature 5

Type: Temperature

Unit: $K$

Time: 78000

$25.03 .201819: 44$

\begin{tabular}{|l|}
2750,8 Max \\
2665,1 \\
2579,4 \\
2493,7 \\
2408 \\
2322,3 \\
2236,6 \\
2150,9 \\
2065,2 \\
1979,5 Min
\end{tabular}

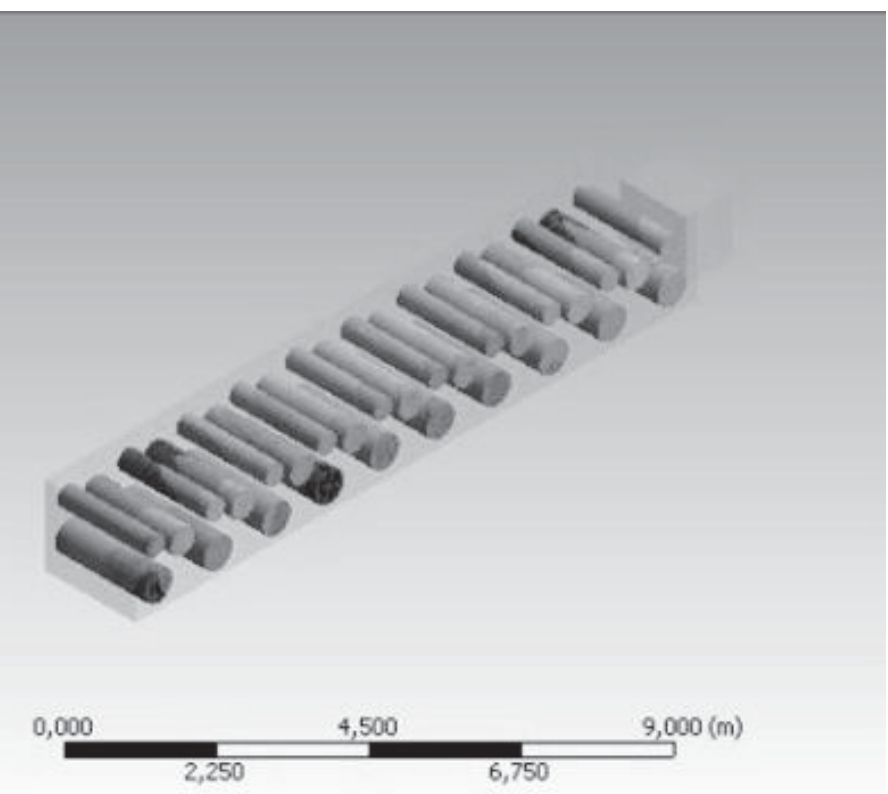

Рис. 4 - Температурні поля на розрізі печі по заготовкам (комбіноване завантаження) 
Подальше моделювання продовжувалось до досягнення заготовками температури близько 3000 $\mathrm{C}$ (рис. 1 , 5-7). 3 цим пов'язаний різний час моделювання ( 22 год., 34 год., 60 год. та 41 год. при умові завантаження заготовками діаметром відповідно 400, 500 та 600 мм, а також при комбінованому завантаженні).

Результати дослідження, представлені на рис. 1, 5 - 8, свідчать про те, що нагрівання заготовок при різних типах завантаження печі відбувається із суттєво різною інтенсивністю.

У той же час розташування заготовок 3 найменшою та найбільшою температурами фактично залишається незмінним. Змінюються лише абсолютні значення їх температур та час нагрівання до потрібної температури.

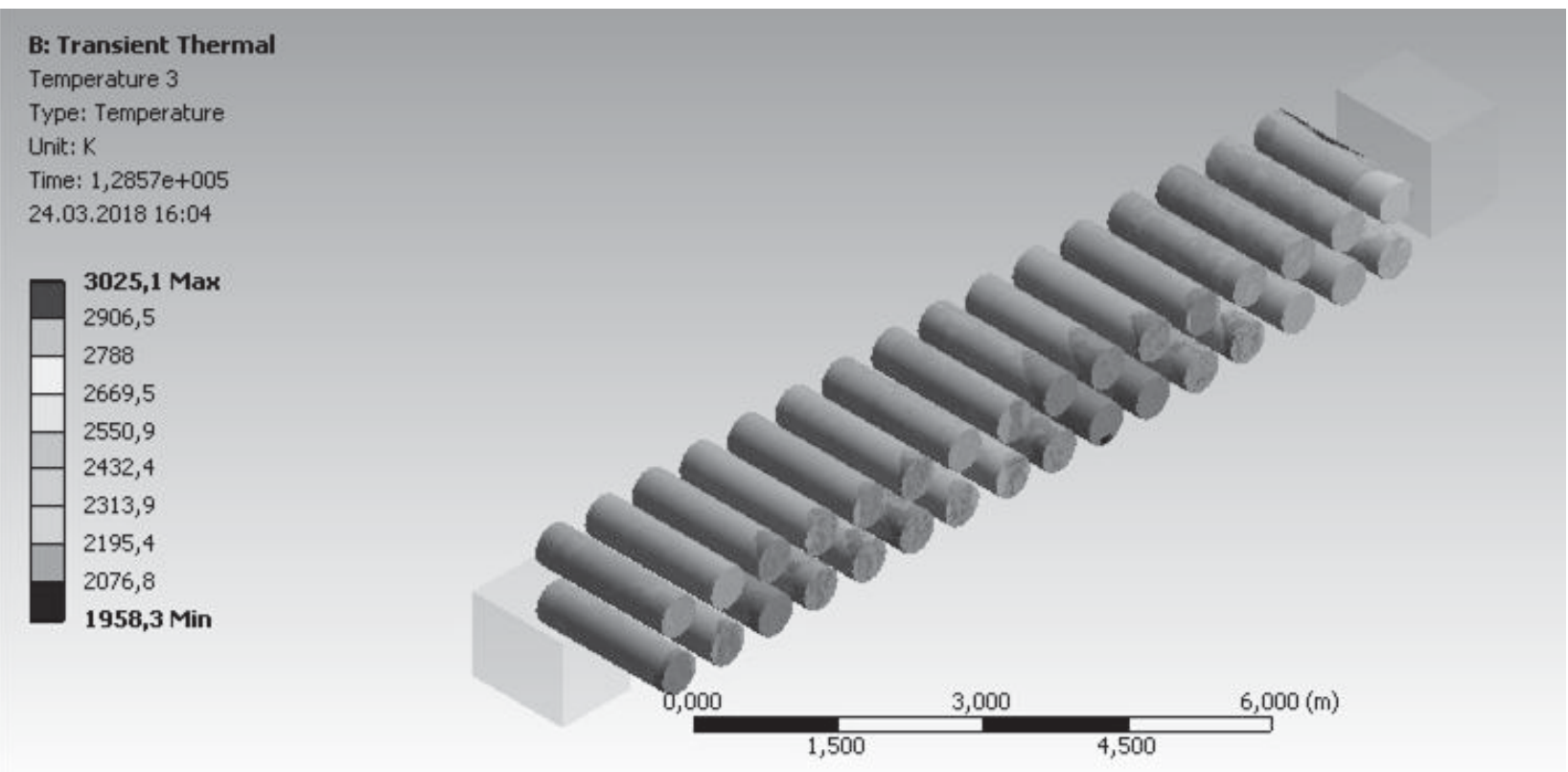

Рис. 5 - Температурні поля на розрізі печі по заготовкам (нагрівання 34 год.) (діаметр виробів 500 мм)

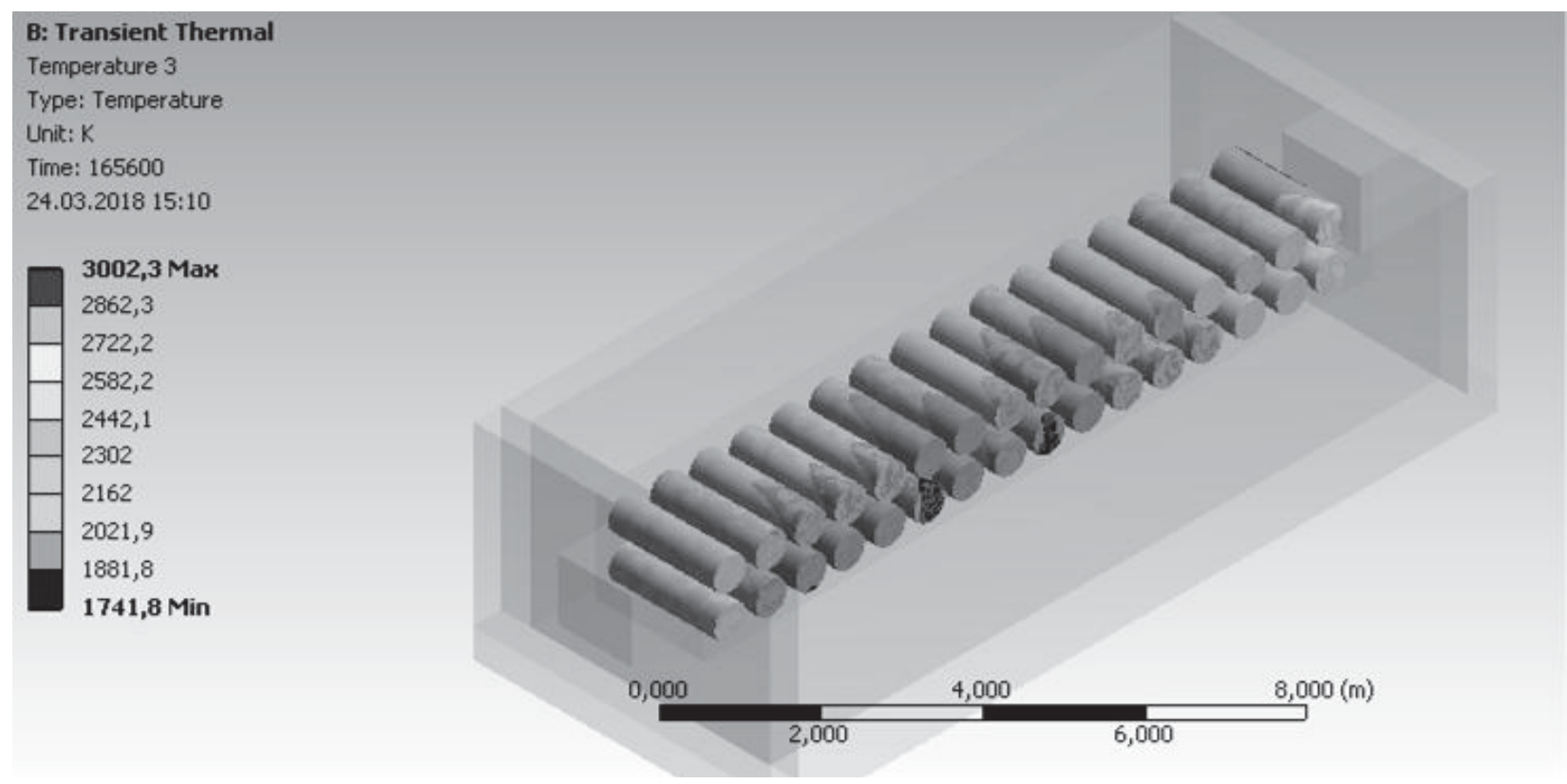

Рис. 6 - Температурні поля на розрізі печі по заготовкам (нагрівання 60 год.) (діаметр виробів 600 мм) 


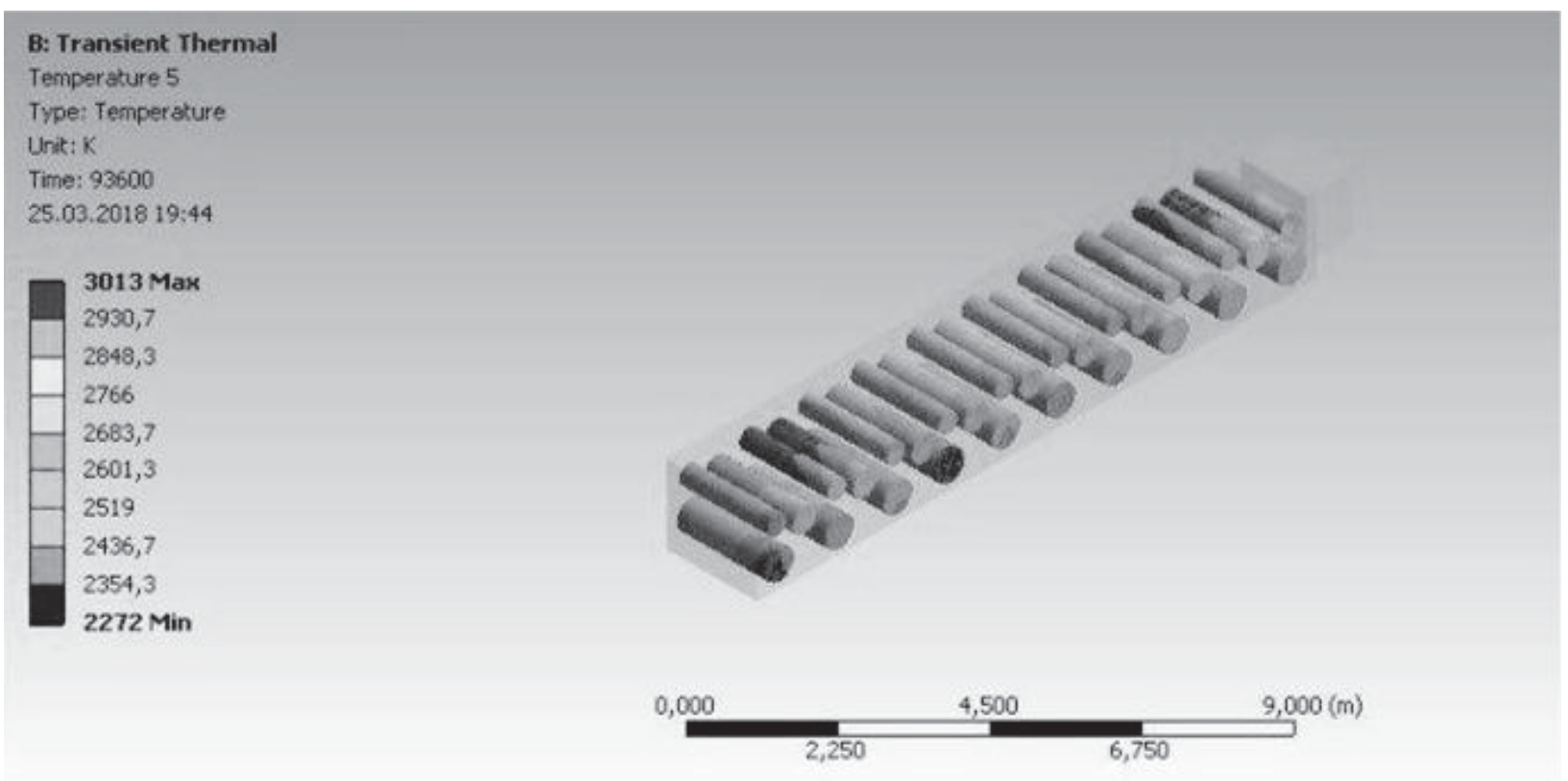

Рис. 7 - Температурні поля на розрізі печі по заготовкам (нагрівання 41 год.) (комбіноване завантаження)

Графік зміни максимальних температур заготовок, показаний на рис. 8.

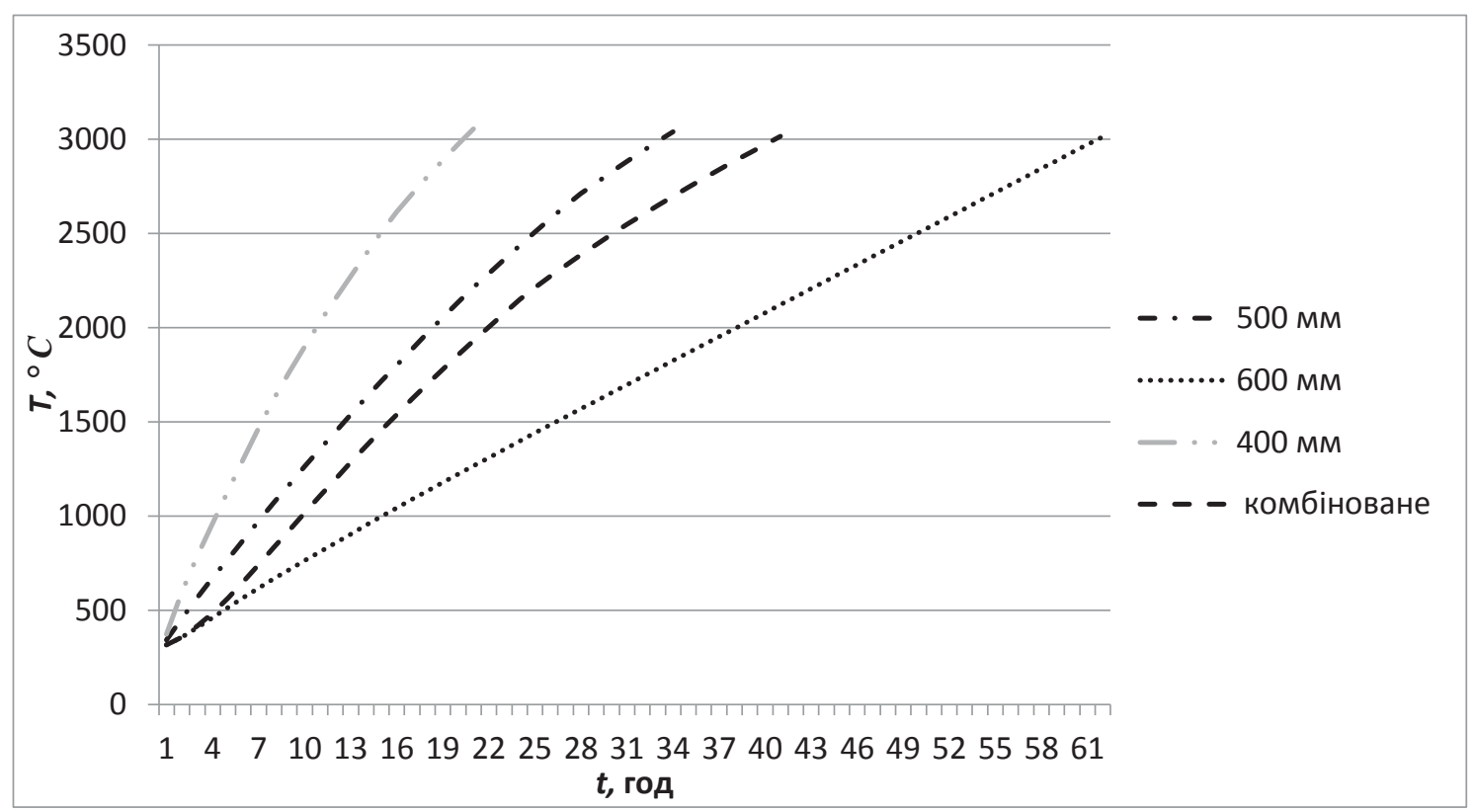

Рис. 8 - Графік зміни максимальної температури по заготовкам при нагріванні

Заготовки з максимальною температурою знаходяться у торці печі з боку струмопідводу $(1,2)$ та на периферії верхнього ряду укладки (4). Це пов'язано з тим, що дані заготовки у найбільшій мірі контактують 3 пересипкою, а значить отримують більше тепла. Найменш нагрітими заготовками є розташовані у протилежному торці печі $(5,6)$ та на периферії нижнього ряду укладки (3) (рис.9). Температурні режими саме цих характерних заготовок і будуть предметом подальших досліджень. 11

Графіки зміни максимальної та мінімальної температур для заготовок діаметром 500 мм представлені на рис. 10 та

На рис. 12 показано яким чином змінюється перепад температур у характерних заготовках у процесі їх нагрівання. Найбільший перепад температур спостерігається у заготовках, що найшвидше нагріваються $(1,2)$. 


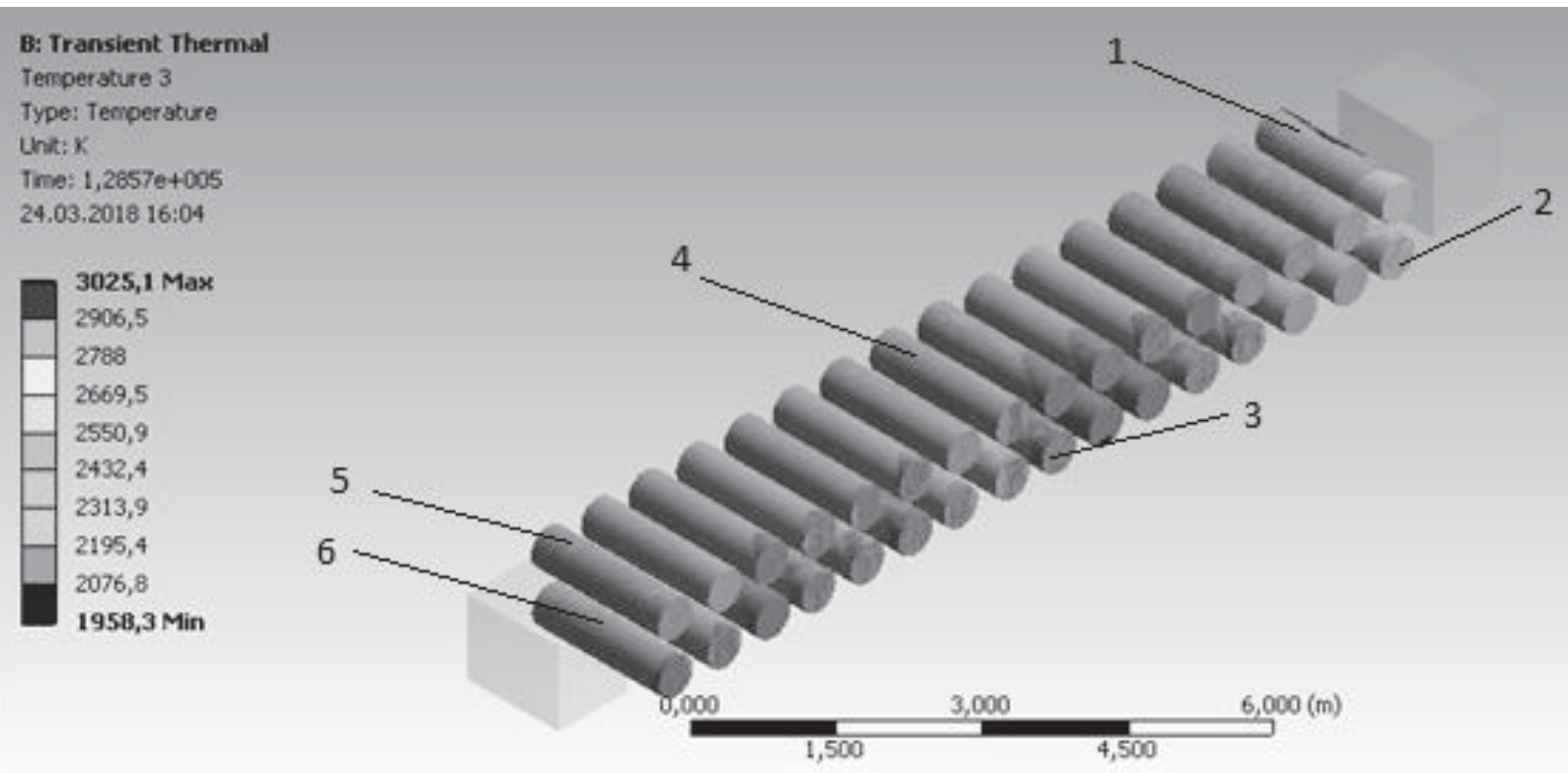

Рис. 9 - Розташування характерних заготовок

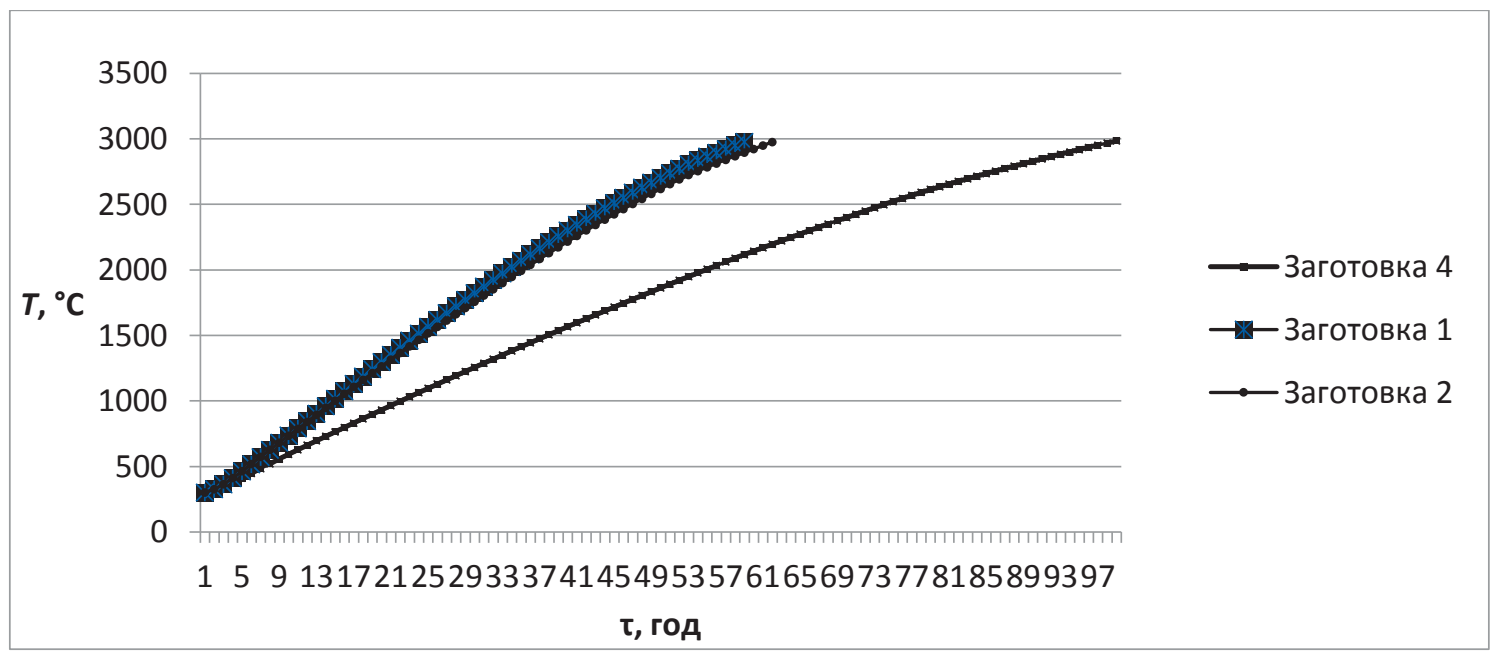

Рис. 10 - Графік зміни максимальної температури для заготовок діаметром 500 мм

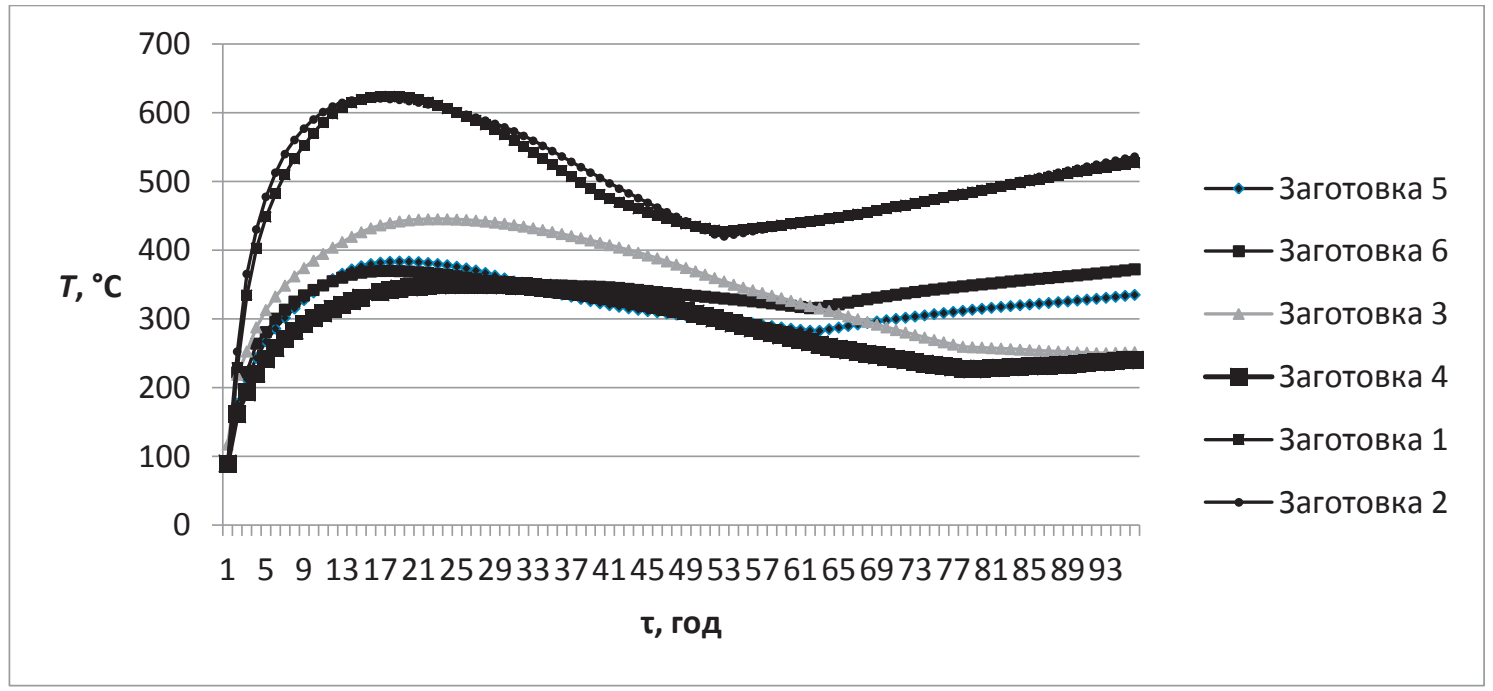

Рис. 11 - Графік зміни мінімальної температури для заготовок діаметром 500 мм 

http://www.atbp.onaft.edu.ua/

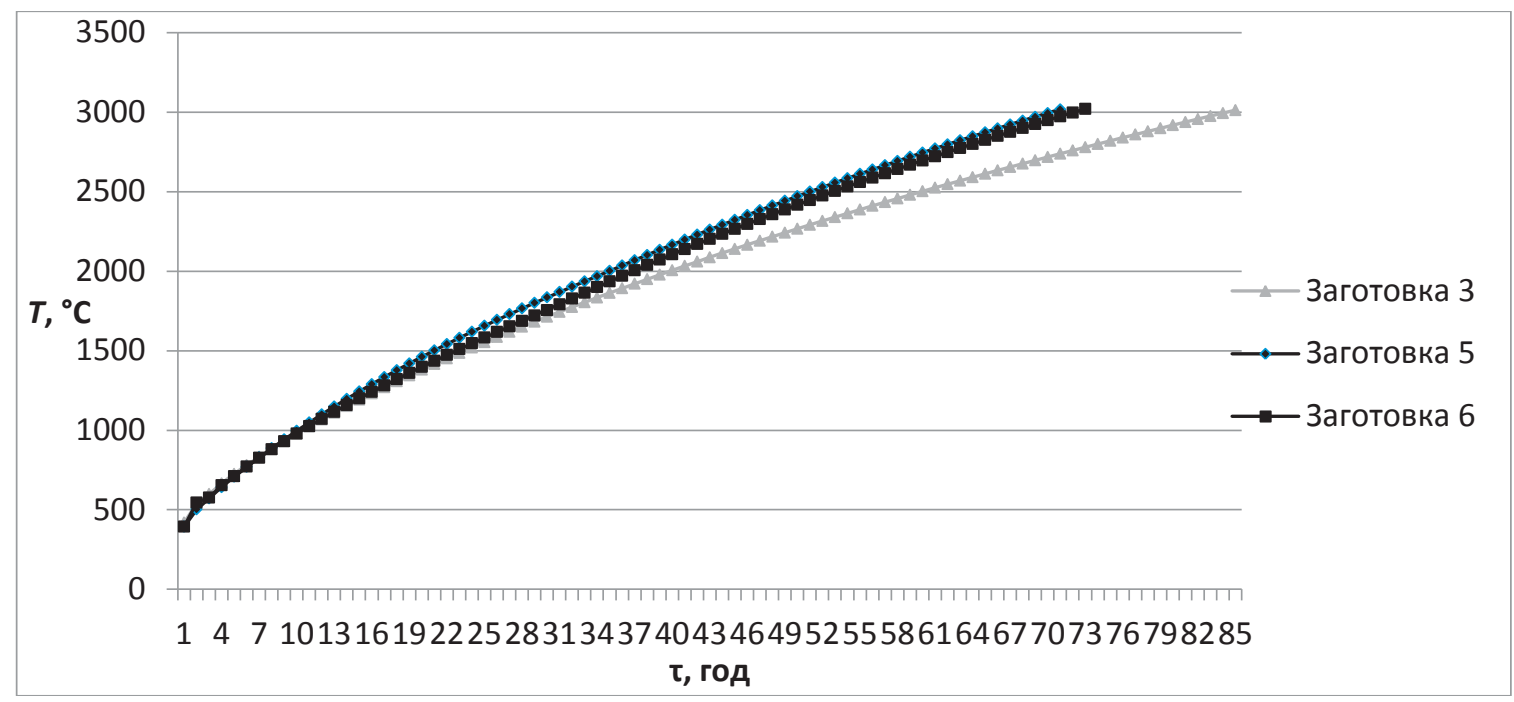

Рис. 12 - Графік перепаду температур при нагріванні у характерних заготовках (діаметром 500 мм)

Характерною особливістю процесу нагрівання $є$ те, що найбільший перепад температур в усіх заготовках спостерігається фактично в один і той самий час (приблизно 27 год.), але цей час різний для різних діаметрів.

Режим охолодження

Результати моделювання температурних полів вуглецевих заготовок після 20-ти годин охолодження представлені на рис. 13-16. Як випливає 3 представлених результатів найшвидше остигають заготовки на торцях печі $(1,2,5,6)$ та на периферії верхнього ряду укладки (3). Що стосується останньої обставини, то це пояснюється знову ж таки більшою контактною поверхнею цих заготовок з пересипкою, що сприяє швидшому охолодженню. Заготовки на торцях у найбільшій мірі наближені до зовнішнього (холодного) середовища.

Графік зміни середньої температури по заготовкам при охолодженні у заготовках різного діаметру показаний на рис. 17.

Результати дослідження зміни температури у часі у характерних заготовках діаметром 500 мм, що охолоджуються найшвидше та найповільніше, представлені на рис. 17. Дослідження проводилося до досягнення заготовками температури $2000{ }^{\circ} \mathrm{C}$, тобто до закінчення процесу графітування. Як і очікувалось, швидкість охолодження заготовок залежить від їх розмірів: чим більший діаметр заготовок, тим довше вони остигають, причому різниця у тривалості охолодження досить суттєва.

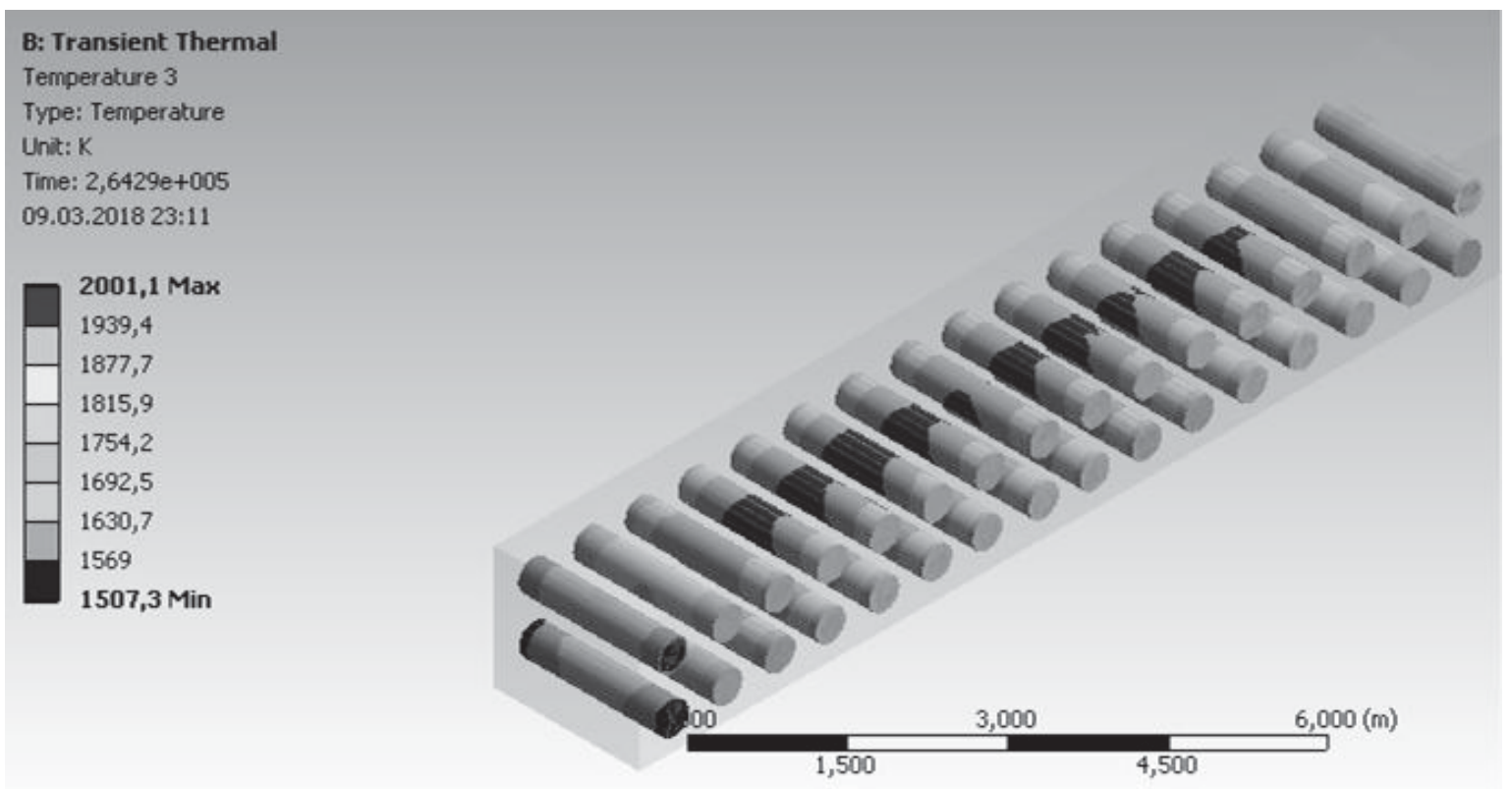

Рис.13 - Температурні поля на розрізі печі по заготовкам (діаметр виробів 400 мм) 


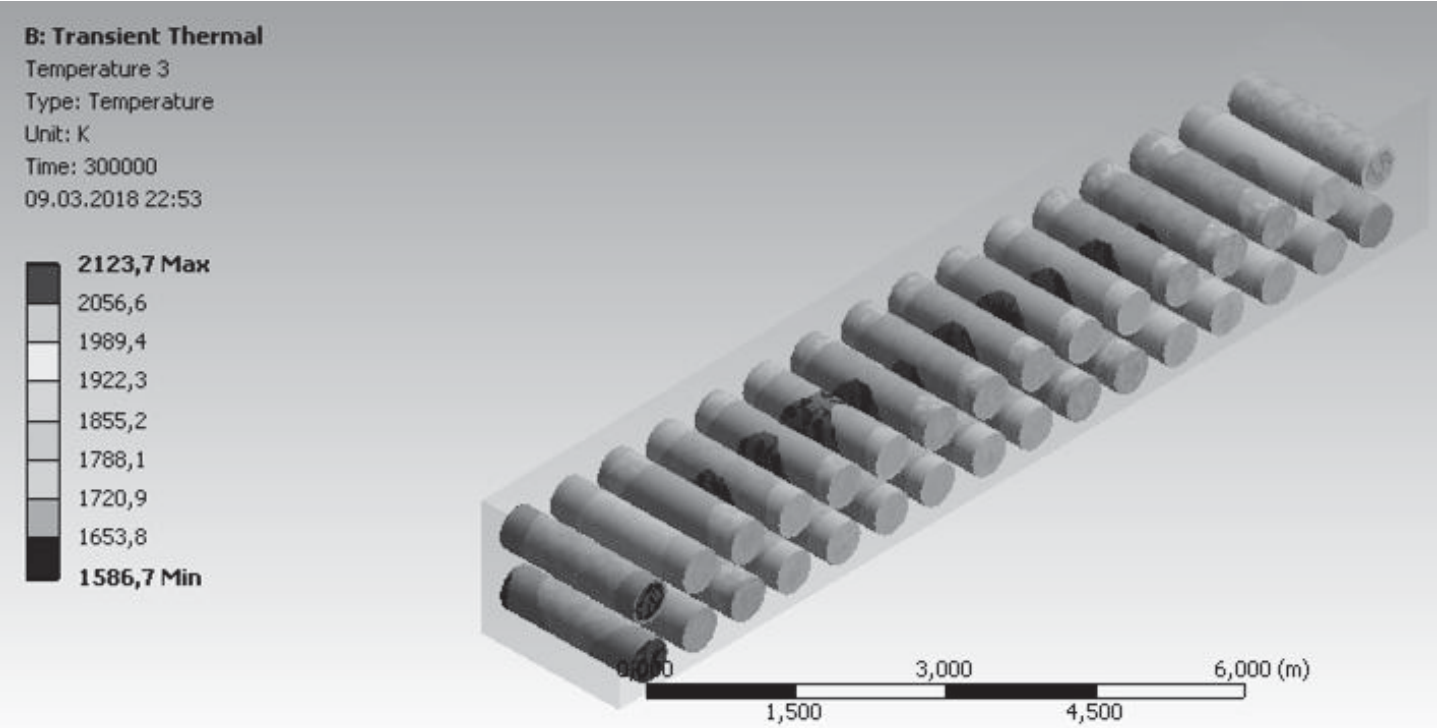

Рис. 14 - Температурні поля на розрізі печі по заготовкам (діаметр виробів 500 мм)

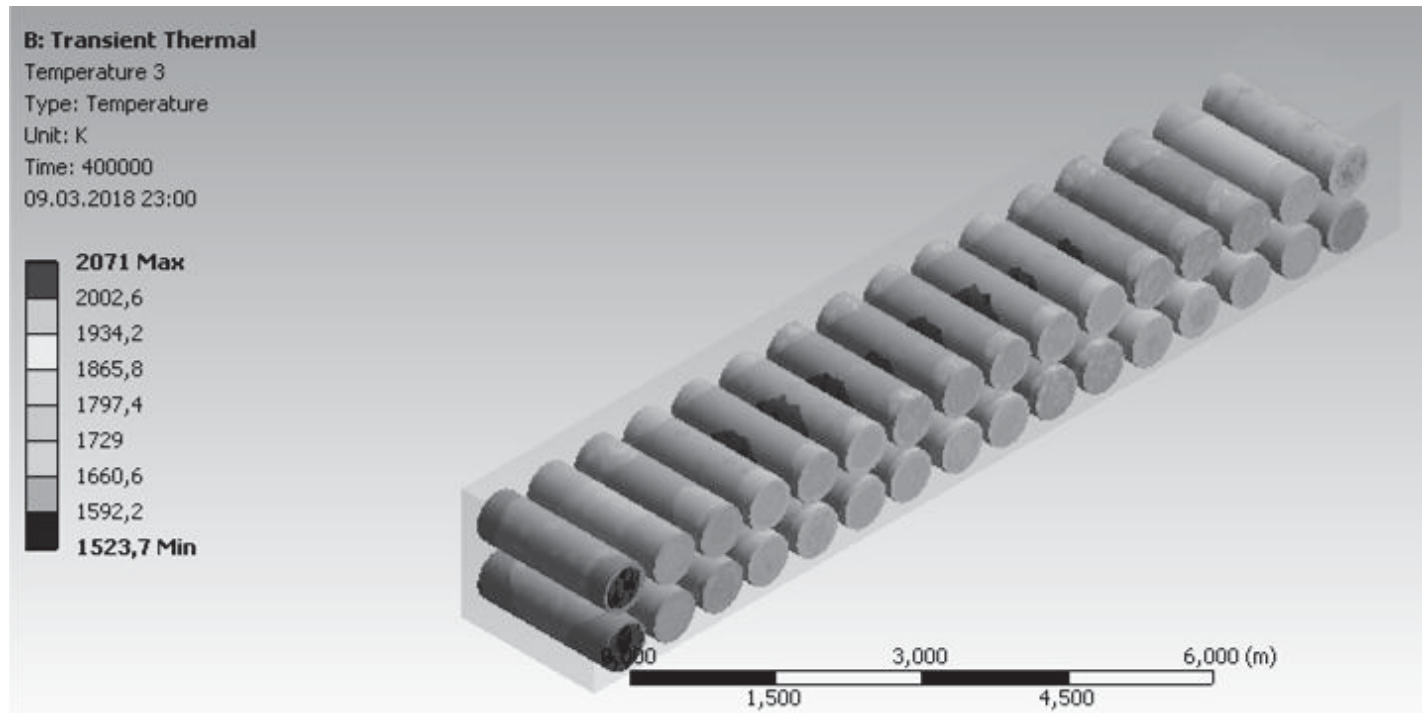

Рис. 15 - Температурні поля на розрізі печі по заготовкам (діаметр виробів 600 мм)

B: Transient Thermal
Temperature 3
Type: Temperature
Unit: K
Time: 93600
10.03.2018 0:09

\begin{tabular}{|l}
3013 Max \\
2930,7 \\
2848,3 \\
2766 \\
2683,7 \\
2601,3 \\
2519 \\
2436,7 \\
2354,3 \\
2272 Min
\end{tabular}

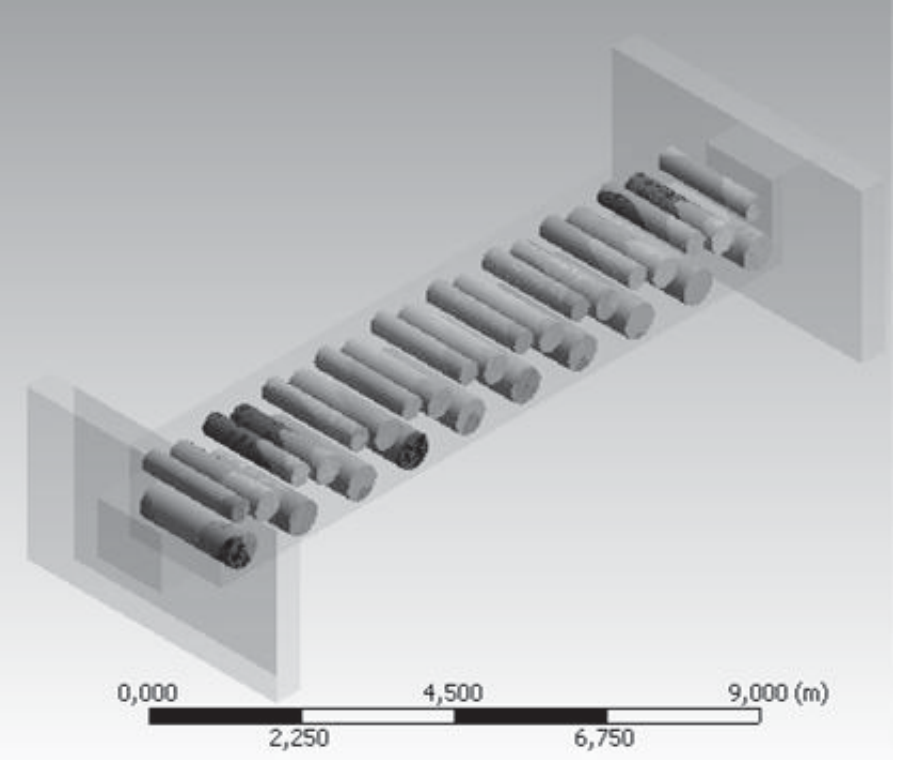

Рис. 16 - Температурні поля на розрізі печі по заготовкам (комбіноване завантаження) 


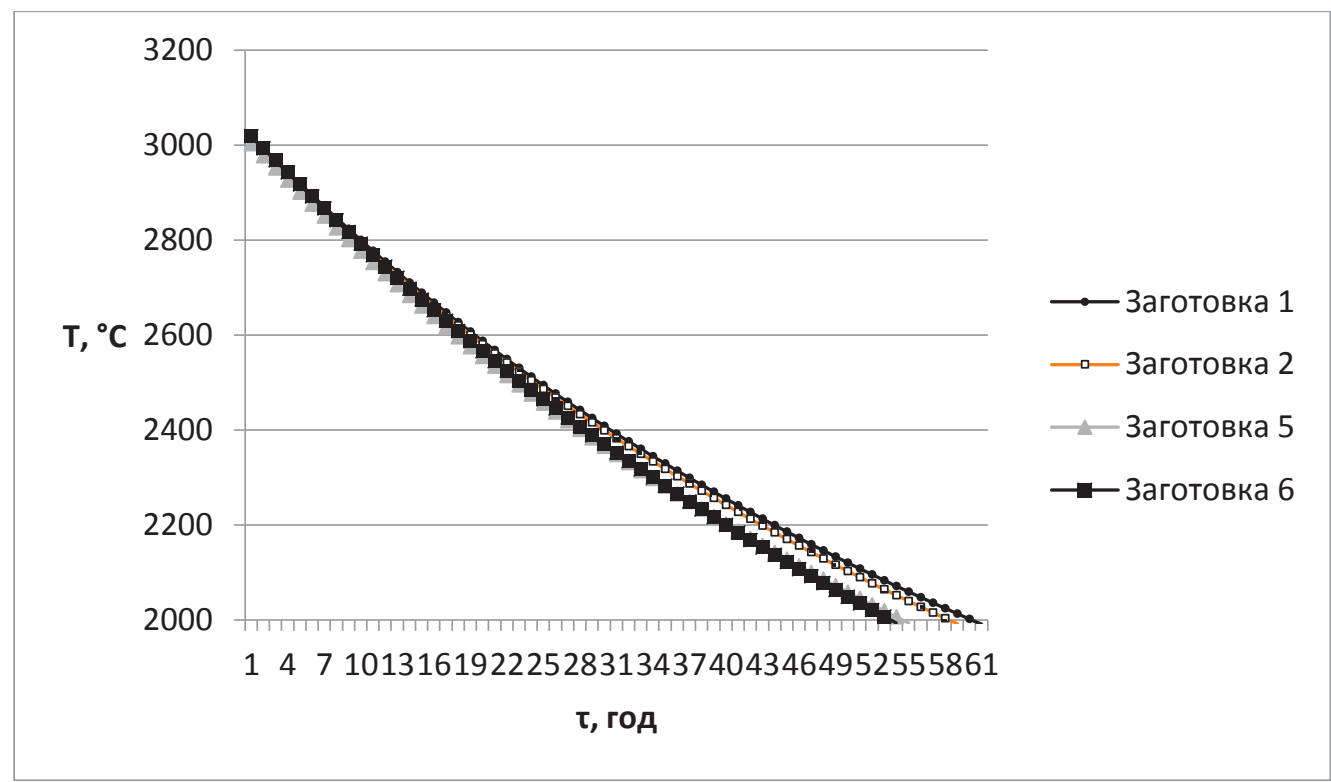

a)

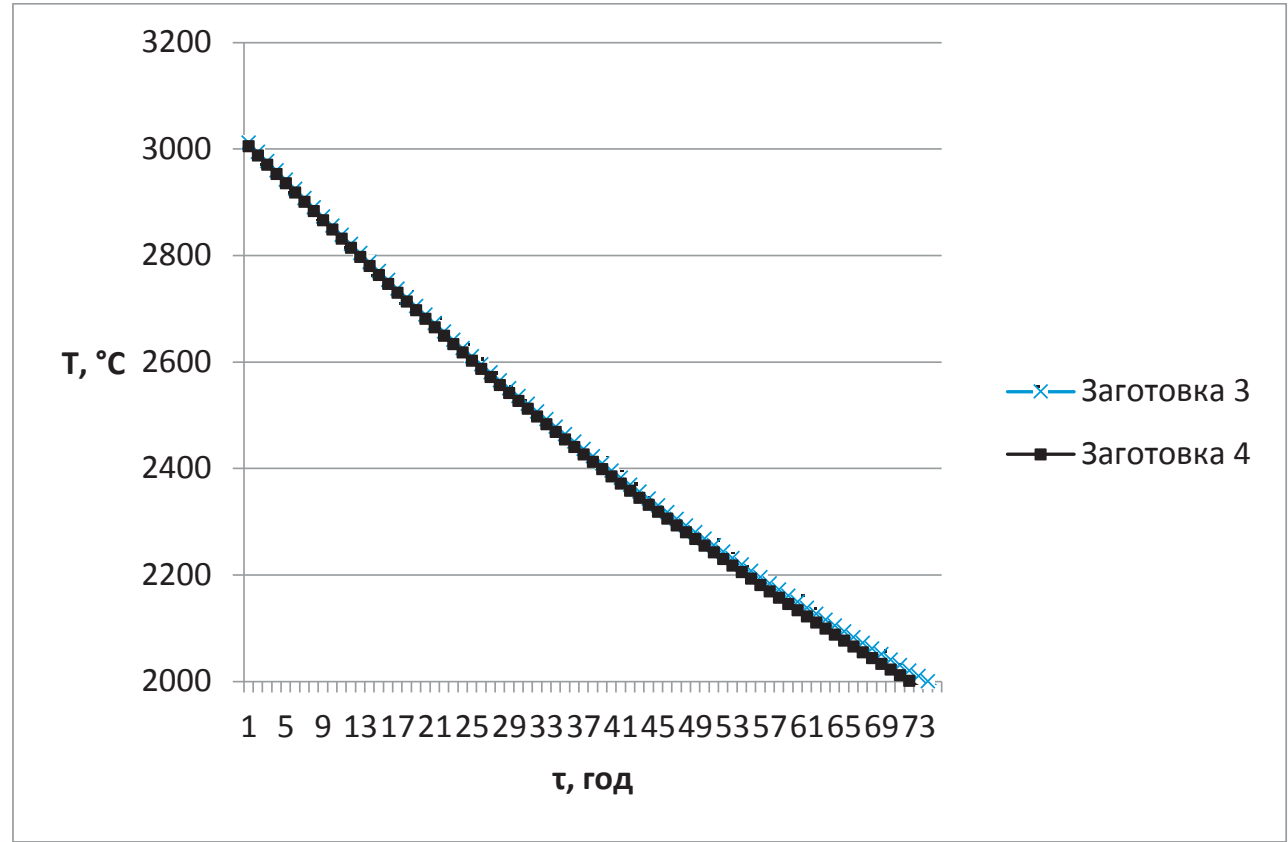

б)

Рис. 17 - Графік зміни температури у часі у характерних заготовках діаметром 500мм, що найшвидше (а) та найповільніше (б) охолоджуються

\section{Висновки}

Результати проведеного дослідження свідчать про те, що температурні поля процесу графітування вуглецевих виробів як у режимі нагрівання, так і у режимі охолодженні суттєво залежать від типу заготовок, що завантажуються у піч, а також від їх розташування. Ця обставина не дозволяє сформувати єдину програму ведення технологічного процесу і ставить задачу адаптації технологічного регламенту до виробничої ситуації, що утворилася. Особливої складності ця задача набуває тоді, коли мають місце непередбачувані відключення печі графітування від енергопостачання.

Враховуючи суттєву температурну розподіленість процесу графітування, визначені місця розташування заготовок 3 найбільшою та найменшою температурою як у режимі нагрівання, так і у режимі охолодження. Це дозволяє 3 більшою точністю визначити потрібну тривалість процесу графітування до досягнення виробами заданого ступеня графітування.

Як показали результати проведеного дослідження, місця розташування характерних заготовок практично не змінюються у залежності від типу завантаження печі. 
Для запобігання порушення механічної міцності вуглецевих виробів у процесі графітування потрібно забезпечити такі режими роботи, які не призводять до перевищення певного перепаду температур у заготовках. Проведене дослідження дозволило виявити місця розташування заготовок з найбільшими перепадами температур та динаміку останніх у процесі графітування.

На підставі проведеного дослідження повинна бути розроблена система керування процесом графітування вуглецевих виробів, що і є предметом подальших досліджень.

\section{Список використаних джерел}

[1] Коржик М. В. Математичне моделювання та автоматизоване керування процесом графітації в печах Ачесона [Текст]: Автореф. дис. канд. техн. наук : 05.13.07 / Коржик М. В.; Мін. освіти і науки України, НТУУ «КПІ». Київ, 2010. - 19 с. - укр.

[2] Лутков А. И. Тепловые и электрические свойства углеродных материалов [Текст] / А. И. Лутков. - М. : Металлургия, 1990. - 175 с.

[3] Franklin R. E. The structure of graphitic carbons / R. E. Franklin, // Acta Crystallographica. - 1951. Vol.4. - P. 253 261.

[4] Чичулин Н. И. Исследование режимов нагревания электродных заготовок при графитации [Текст] / Н. И. Чичулин, В. П. Соседов, Е. Ф. Чалых // Совершенствование технологии и улучшение качества электродной продукции : сб. научн. тр., Вып.6. - Челябинск : ГосНИИЭП., 1974. - С. 128 - 134.

[5] Соседов В. П. О рациональном графике подъема мощности и температуры в процессе графитации [Текст] / В. П. Соседов, В. Б. Сасс-Тисовский, А. С. Карманов // Цветные металлы. - 1967. - № 2. - С. 62 - 63.

[6] Кузнецов Д. М. Процесс графитации углеродных материалов. Современные методы исследования [Текст] / Д. М. Кузнецов, В. П. Фокин. - Новочеркасск: ЮРГТУ. - 2001. - 132 с.

[7] Лелека С. В. Теплоэлектрическое состояние печей графитирования Ачесона [Текст] :монография/С.В.Лелека, Е.Н.Панов,А.Я.Карвацкий и др.-К.: НТУУ «КПИ», 2014.-238 с.

[8] Карвацкий Ф. Я. Теоретичні та експериментальні дослідження теплоелектричного та механічного стану високотемпературних агрегатів [Текст] : моногр. / Ф.Я.Карвацький, Є.М.Панов, С.В.Кутузов та ін. - К.: НТУУ «ПIІ», 2012.- $352 \mathrm{c}$.

\section{References}

[1] Korzhik M. V. (2010) Matematichne modelyuvannya ta avtomatizovane keruvannya protsesom grafitatsii v pechakh Achesona [Mathematical modeling and automated control of the grafitization in Acheson's furnaces]: Avtoref. dis. kand. tekhn. nauk : 05.13.07; Min. osviti i nauki Ukraine, NTUU «KPI», Kyiv.

[2] Lutkov A. Y. (1990) Teplovye i elektrycheskye svoistva uhlerodnykh materyalov [Thermal and electrical properties of carbon materials], M. : Metallurhyia.

[3] Franklin R. E. (1951) The structure of graphitic carbons, Acta Crystallographica, Vol.4, pp. 253 - 261.

[4] Chychulyn N. Y., Sosedov V. P. and Chalykh E. F. (1974) " Research of modes of heating of electrode blanks during grafitization", Sovershenstvovanye tekhnolohyy y uluchshenye kachestva эlektrodnoi produktsyy : sb. nauchn. tr., Vol.6. - Cheliabynsk : HosNYYEP, pp. 128 - 134.

[5] Sosedov V. P., Sass-Tysovskyi V. B. and Karmanov A. S. (1967) “On a rational graph of power and temperature rise in the process of grafitization ", Tsvetnye metally. Vol. 2, pp. $62-63$.

[6] Kuznetsov D. M. and Fokyn V. P. (2001) Protsess hrafytatsyy uhlerodnykh materyalov. Sovremennye metody yssledovanyia [The process of grafitization of carbon materials. Modern research methods], Novocherkassk: YuRHTU.

[7] Leleka S. V. and Panov E. N. (2014) Teploelektrycheskoe sostoianye pechei hrafytyrovanyia Achesona [Thermoelectric state of Acheson grafitization furnaces] :monohrafyia, K.: NTUU «KPY».

[8] Karvatskyi F. Ya., Panov E. M. and Kutuzov S. V. (2012) Teoretychni ta eksperymentalni doslidzhennia teploelektrychnoho ta mekhanichnoho stanu vysokotemperaturnykh ahrehativ [Theoretical and experimental studies of the heat-mechanical and mechanical state of high-temperature aggregates]: monohr, K.: NTUU «KPI». 